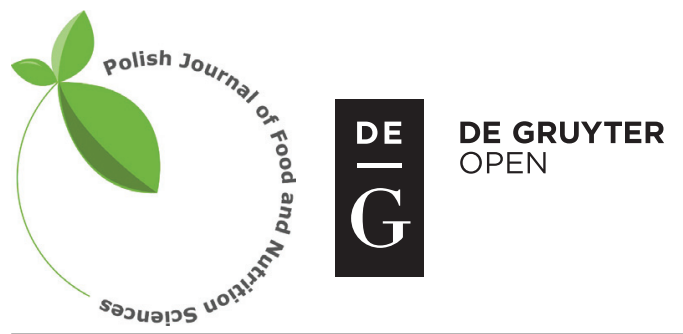

Pol. J. Food Nutr. Sci., 2017, Vol. 67, No. 1, pp. 33-39

DOI: $10.1515 /$ pjfns-2016-0002 http://journal.pan.olsztyn.pl

Original article

Section: Food Technology

\title{
Synthesis of Galactosyl Mannitol Derivative Using $\beta$-Galactosidase from Kluyveromyces lactis
}

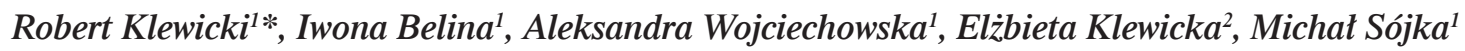 \\ ${ }^{1}$ Lodz University of Technology, Institute of Food Technology and Analysis, Stefanowskiego 4/10, 90-924 Łódź, Poland \\ ${ }^{2}$ Lodz University of Technology, Institute of Fermentation Technology and Microbiology, \\ Wólczańska 171/173, 90-924 Łódź, Poland
}

Key words: mannitol, $\beta$-galactosidase, transglycosylation, lactose

The purpose of the study was to identify the influence of reactive mixture concentration $(23-48 \mathrm{~g} / 100 \mathrm{~mL}), \mathrm{pH}(6.5-9.0)$, presence of $\mathrm{NaCl}$ $(0.05-0.25 \mathrm{~mol} / \mathrm{L})$ and enzyme dose (2850-28,500 LAU/100 $\mathrm{g}$ of lactose) on the synthesis of galactosyl mannitol derivative using $\beta$-galactosidase from Kluyveromyces lactis. The use of the enzyme dose ranging from 2850 to 11,400 LAU/100 g lactose allowed obtaining gal-mannitol at the level of $21.8 \%$ total saccharides; higher doses intensified product decomposition. An increase in the concentration of the reactive mixture had a positive impact on the quantity of gal-mannitol obtained every single time, i.e. $4.39 \mathrm{~g}$ were obtained from $100 \mathrm{~mL}$ of a $23 \mathrm{~g} / 100 \mathrm{~mL}$ solution and over $10 \mathrm{~g}$ were obtained from a $48 \mathrm{~g} / 100 \mathrm{~mL}$ solution. A relatively low increase in product quantity (by $c a .5 \%$ ) occurred after the $\mathrm{pH}$ was increased from 6.5 to 9.0 . The use of $\mathrm{NaCl}$ rendered better results. An increase in the maximum content of gal-mannitol in the total sugar by $12.8 \%$ was observed at the concentration of $0.25 \mathrm{~mol} / \mathrm{L}$.

\section{INTRODUCTION}

Substances with a saccharide-polyol structure demonstrate interesting characteristics. Once used in the diet of rats, they have a positive influence on the parameters of blood and cecum [Juśkiewicz et al., 2006]. In their presence, lactic acid bacteria reveal antagonistic action against selected pathogens [Klewicki \& Klewicka, 2004]. Lactitol (combination of galactose and sorbitol) has prebiotic properties, typical of transglycosylation products (oligosaccharides) [Saarela et al., 2003] with properties characteristic of alditols such as low hygroscopicity, reduced energy value, low susceptibility to non-enzymatic browning, resistance to hydrolysis and increased temperature [Linden \& Lorient, 1999]. Lactitol is the only compound of that kind which is relatively cheap and commonly available on the market. It is obtained by catalytic hydrogenation of lactose. It is used as a sweetening agent [Seki \& Saito, 2012]. Besides lactulose, lactitol is also used as an anti-hepatic encephalopathy agent [Sharma \& Sharma, 2013].

The volume of data on enzymatic synthesis of galactosyl-polyols is relatively limited in the literature. Synthesis is based on the use of transglycosylation properties of $\beta$-galactosidase. Galactooligosaccharides are generated in lactose solutions by attaching a galactosyl residue to the saccharides present in the reaction medium [Guerrero et al., 2015]. The presence of polyol besides lactose in the reactive mixture makes

\footnotetext{
* Corresponding Author: E-mail: robert.klewicki@p.lodz.pl physiological calorific value amounts to $1.6 \mathrm{kcal} / \mathrm{g}$, which

transglycosylation activity of the enzyme greatly oriented towards the synthesis of gal-polyols. Glycerol seems to be most commonly used as the acceptor, according to the reports on the issue. Wei et al. [2013], Cardelle-Cobas et al. [2009] and Stevenson et al. [1993] used $\beta$-galactosidase from Kluyveromyces lactis for the synthesis of its galactosyl derivative. Irazoqui et al. [2009] used an enzyme from Aspergillus oryzae. Nakano et al. [2003] obtained a glucose derivative of glycerol carrying out the reaction in the mixture of soluble starch and glycerine using cyclodextrin glucanotransferases. Moreover, $\alpha$-galactosyl derivative was obtained by using guar gum as a source of galactose and $\alpha$-galactosidase from Aspergillus sp. MK14 [Kurakake et al., 2015]. Sorbitol was another polyhydroxyalcohol used as an acceptor. Klewicki [2007a] used $\beta$-galactosidase from Kluyveromyces fragilis, Kluyveromyces lactis and Aspergillus oryzae. Lu et al. [2009] used an enzyme from Enterobacter cloacae for gal-sorbitol synthesis. Moreover, the following compounds were also used as acceptors: erythritol [Irazoqui et al., 2009; Klewicki, 2007a], maltitol (using cyclodextrin glucanotransferase) [Kim et al., 1997] and lactitol [Klewicki, 2007a; Yanahira et al., 1997]. The possibility of attaching a galactosyl residue (as well as other saccharides) to an acceptor other than sorbitol, provides conditions for obtaining gal-polyols with properties potentially different than these of lactitol. It provides good prospects for the development of the market of prebiotics.

The paper presents conditions of gal-mannitol synthesis. Mannitol itself demonstrates interesting properties. Its 
is 2.5 times lower than that of sucrose. It is about half less sweet, though, and is used as an agent improving products texture. It reduces sugar tendency to crystallize. Its hygroscopicity is low, hence products containing mannitol are more stable under increased humidity. It has a cooling effect and masks unpleasant tastes. In medicine, it is used as a diuretic or agent facilitating drugs transport to the brain [Saha \& Racine, 2011].

In the available literature it is mentioned as an acceptor for galactosyl residues transmitted from $o$-nitrophenyl- $\beta$-D-galactopyranoside (oNPGal) by $\beta$-galactosidase from $E n$ terobacter cloacae B5 [Lu et al., 2009; Lu et al., 2010].

The purpose of the study was to identify the impact of the reactive mixture concentration, $\mathrm{pH}$, temperature and enzyme dose on the synthesis of galactosyl mannitol derivative using $\beta$-galactosidase from Kluyveromyces lactis and lactose as a donor.

\section{MATERIALS AND METHODS}

\section{Materials}

The following compounds and reagents were used in the study: Lactozym - an enzymatic preparation of $\beta$-galactosidase from Kluyveromyces lactis (Novozymes A/S, Bagsvaerd, Denmark); lactose (Bayerische Milchindustrie eG, Landshut, Germany); mannitol (Ubichem, Redditch, United Kingdom); acetonitrile (J.T. Baker from Witko, Łódź, Poland); $\mathrm{KH}_{2} \mathrm{PO}_{4}$ (POCh, Gliwice, Poland), and $\mathrm{Na}_{2} \mathrm{HPO}_{4} \times$ $12 \mathrm{H}_{2} \mathrm{O}$ (POCh, Gliwice, Poland).

\section{Gal-mannitol synthesis in solutions with different contents of dry mass}

$\beta$-Galactosidase in the amount of $11,400 \mathrm{LAU} / 100 \mathrm{~g}$ of lactose (1 LAU is defined as the amount of enzyme which releases $1 \mathrm{mmol}$ glucose per minute under the following standard conditions: $4.75 \%$ (w/w) lactose, $\mathrm{pH} 6.5,37^{\circ} \mathrm{C}$, reaction time $30 \mathrm{~min}$ ) was added to $150 \mathrm{~mL}$ of a reactive mixture containing lactose and mannitol in a $1: 1$ ratio $(w / w)$ with the following dry matter contents: $23,28,33,38,43$ or $48 \mathrm{~g} / 100 \mathrm{~mL}$. The reaction was carried out at $37^{\circ} \mathrm{C}$ for 3 to 8 hours. The $\mathrm{pH}$ value was $6.5 \pm 0.1$ (adjusted with a solution: $\left.3.471 \mathrm{~g} \mathrm{KH}_{2} \mathrm{PO}_{4}+8.954 \mathrm{~g} \mathrm{Na}_{2} \mathrm{HPO}_{4} \times 12 \mathrm{H}_{2} \mathrm{O} / 100 \mathrm{~mL}\right)$. Samples $(10 \mathrm{~mL})$ were collected every 30 minutes. Experiments were performed in two replications.

\section{Gal-mannitol synthesis using different enzyme doses}

The following quantities of $\beta$-galactosidase were added to $150 \mathrm{~mL}$ of a $33 \mathrm{~g} / 100 \mathrm{~mL}$ reactive mixture containing lactose and mannitol in a $1: 1$ ratio $(\mathrm{w} / \mathrm{w}): 2850 ; 5700 ; 11,400$; 17,$100 ; 22,800$ or $28,500 \mathrm{LAU} / 100 \mathrm{~g}$ of lactose. The reaction was conducted at $37^{\circ} \mathrm{C}$, for 3 to 8 hours. The $\mathrm{pH}$ level was $6.5 \pm 0.1$ (adjusted with a solution: $3.471 \mathrm{~g} \mathrm{KH}_{2} \mathrm{PO}_{4}+8.954 \mathrm{~g}$ $\left.\mathrm{Na}_{2} \mathrm{HPO}_{4} \times 12 \mathrm{H}_{2} \mathrm{O} / 100 \mathrm{~mL}\right)$. Samples $(10 \mathrm{~mL})$ were collected every 15 or 30 minutes. Experiments were performed in two replications.

\section{Gal-mannitol synthesis in solutions with different pH}

$\beta$-Galactosidase in the amount of $11,400 \mathrm{LAU} / 100 \mathrm{~g}$ of lactose was added to $150 \mathrm{~mL}$ of a $33 \mathrm{~g} / 100 \mathrm{~mL}$ reactive mixture containing lactose and mannitol in a 1:1 ratio $(\mathrm{w} / \mathrm{w})$. The reaction was conducted at $37^{\circ} \mathrm{C}$, for 4 to 10 hours. The $\mathrm{pH}$ level was $6.5 ; 7.5 ; 8.5$ or $9.0 \pm 0.1$ (adjusted with $2 \mathrm{~mol} / \mathrm{L} \mathrm{NaOH}$ solution). Samples $(10 \mathrm{~mL})$ were collected every 30 or 60 minutes. Experiments were performed in two replications.

\section{Gal-mannitol synthesis in the presence of $\mathrm{NaCl}$ of different concentrations}

$\beta$-Galactosidase in the amount of $11,400 \mathrm{LAU} / 100 \mathrm{~g}$ of lactose was added to $150 \mathrm{~mL}$ of a $33 \mathrm{~g} / 100 \mathrm{~mL}$ reactive mixture containing lactose and mannitol in a $1: 1$ ratio $(\mathrm{w} / \mathrm{w})$ and $0.05 \mathrm{~mol} / \mathrm{L}, 0.1 \mathrm{~mol} / \mathrm{L}$ or $0.25 \mathrm{~mol} / \mathrm{L} \mathrm{NaCl}$. The reaction was conducted at $37^{\circ} \mathrm{C}$, for 4 to 10 hours. The $\mathrm{pH}$ level was $6.5 \pm 0.1$ (adjusted with a solution: $3.471 \mathrm{~g} \mathrm{KH}_{2} \mathrm{PO}_{4}+8.954 \mathrm{~g}$ $\left.\mathrm{Na}_{2} \mathrm{HPO}_{4} \times 12 \mathrm{H}_{2} \mathrm{O} / 100 \mathrm{~mL}\right)$. Samples $(10 \mathrm{~mL})$ were collected every 60 minutes. Experiments were performed in two replications.

\section{Identifying gal-mannitol content using HPLC method}

A sample $(10 \mathrm{~mL})$ of the reactive mixture was introduced into $20 \mathrm{~mL}$ of boiling distilled water; boiling was maintained for 3 minutes. After cooling down to room temperature, it was placed in a $50 \mathrm{~mL}$ volumetric flask and filled up with water. It was filtrated after mixing. A $5 \mathrm{~mL}$ sample was desalinated using a column containing a mixture of cationite and anionite $(1: 2)$. The first part of the filtrate $(3 \mathrm{~mL})$ was removed and another $2 \mathrm{~mL}$ were collected and sent for HPLC analysis (KNAUER). Separation conditions were as follows: column - Shodex Asahipak $\mathrm{NH}_{2} \mathrm{P}$, mobile phase - acetonitrile: water (80:20 ratio), flow rate $-0.8 \mathrm{~mL} / \mathrm{min}$, detector $-\mathrm{RI}$.

\section{MS analysis of gal-mannitol}

The gal-mannitol peak was collected from five repeated HPLC separations. The obtained sample was then subjected to MS detector Q Exactive Orbitrap equipped with HESI probe (Thermo Scientific, Waltham, MA, USA). The sample was directly injected $(10 \mu \mathrm{L} / \mathrm{min})$ into MS detector. Analyses utilized the negative ion mode. The source parameters were as follows: ion spray voltage, $3.00 \mathrm{kV}$; capillary temperature, $300^{\circ} \mathrm{C}$; and sheath gas and auxiliary gas, 10 and 0 units/min, respectively.

\section{Statistical analysis}

STATISTICA 10 (StatSoft. Inc., USA) was used to create figures. Mean values \pm standard deviation were presented.

\section{RESULTS AND DISCUSSION}

The tendency to use transglycosylation products as substrates at a significant degree of using the basic substrate is the unfavorable property of glycosidases; and in the case of $\beta$-galactosidase this phenomenon is observed for far reached lactose hydrolysis [Rodriguez-Colinas et al., 2014; Manera et al., 2012]. The reduced content of gal-polyols in the reactive mixture is also attributed to this phenomenon. Therefore, identifying the right dose of the enzyme in relation to the reaction time is an essential factor for selecting optimum conditions for synthesis of transglycosylation products 


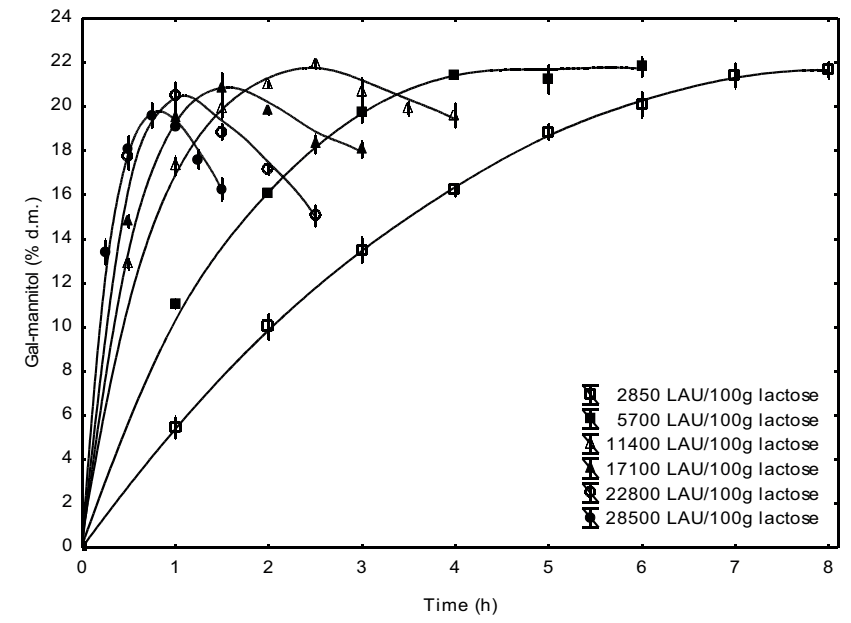

FIGURE 1. Changes in the content of gal-mannitol in the total sugar during synthesis in $33 \mathrm{~g} / 100 \mathrm{~mL}$ solution of lactose and mannitol (1:1 ratio, w/w) depending on the enzyme dose. Reaction conditions: $37^{\circ} \mathrm{C}, \mathrm{pH} 6.5$, $\beta$-galactosidase from Kluyveromyces lactis.

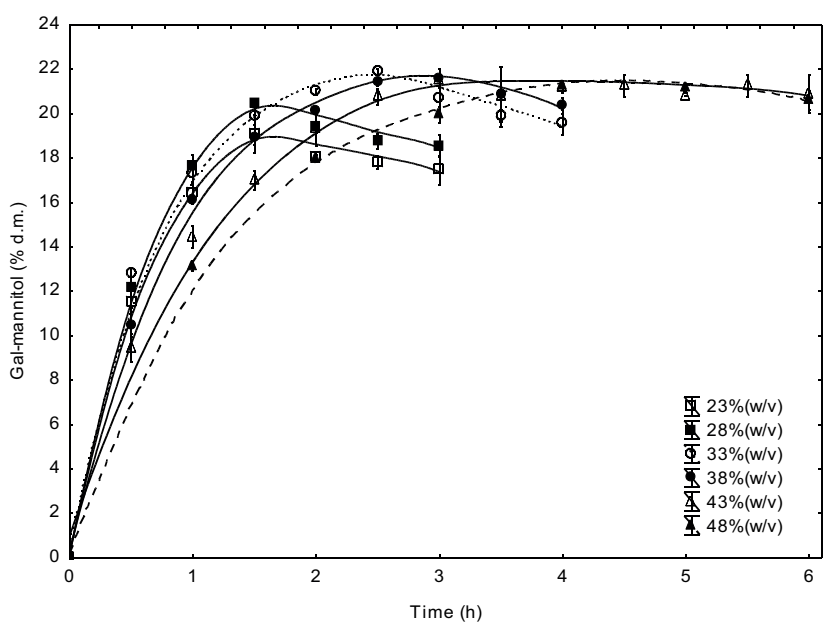

FIGURE 2. Changes in the content of gal-mannitol in the total sugar during synthesis in a solution of lactose and mannitol (1:1 ratio, $\mathrm{w} / \mathrm{w})$ depending on the dry mass content. Reaction conditions: $37^{\circ} \mathrm{C}$, $\mathrm{pH} 6.5$, $\beta$-galactosidase from Kluyveromyces lactis in the amount of $11400 \mathrm{LAU} / 100 \mathrm{~g}$ of lactose.

[Del-Val et al., 2001]. From the point of view of the obtained maximum content of gal-mannitol, using the enzyme dose from 2850 to $11,400 \mathrm{LAU} / 100 \mathrm{~g}$ of lactose provides similar results (product content in the total sugar of $c a .21 .8 \%$; Figure 1). The dose increase to $22,800 \mathrm{LAU} / 100 \mathrm{~g}$ of lactose resulted in an almost $7 \%$ decrease in the maximum content of gal-mannitol. A ten-fold increase in the quantity of $\beta$-galactosidase caused the value decrease by $c a$. $10 \%$. However, increasing the enzyme dose significantly modified the reaction time to reach the product content close to the maximum. Although the time for the lowest dose is $c a$. 6 hours, the dose increase to 17,100 LAU/100 g of lactose reduces the time to 1.5 hours, while only an hour is sufficient for a ten-fold higher dose. It shall be emphasized that although for the two lowest doses no reduction in the content of galmannitol was observed, for the dose of 17,100 LAU/100 g of lactose extending the reaction time by an hour resulted in a $12.8 \%$ loss in the product content, and for the dose of $22800 \mathrm{LAU} / 100 \mathrm{~g}$ of lactose - in a $16.1 \%$ loss.

The content of lactose in the reactive mixture is an important factor influencing the efficiency of galactooligosaccharide synthesis [Iwasaki et al., 1996; Sen et al., 2014]. An increase in its concentration causes reduction in water activity in the mixture, which reduces the hydrolytic activity of $\beta$-galactosidase [Hansson et al., 2001]. Transglycosylation products are formed more intensively. An increase in the concentration is, however, limited by a limited lactose solubility; in solutions for obtaining galactooligosaccharides the concentration reaches $55 \mathrm{~g} / 100 \mathrm{~g}$ [Manera et al., 2012; Shin \& Yang, 1994; Tzortzis et al., 2005]. The use of higher concentrated solutions $(33-48 \mathrm{~g} / 100 \mathrm{~mL})$ in the performed tests provided double benefits (Figure 2). Firstly, a certain increase in the maximum content of gal-mannitol in the total sugar was observed (from 19.1\% in $23 \mathrm{~g} / 100 \mathrm{~mL}$ solution to $21.9 \%$ in $33 \mathrm{~g} / 100 \mathrm{~mL}$ solution). Simultaneously, the product quantity obtained individually from $100 \mathrm{~mL}$ of the solution increased from $4.39 \mathrm{~g}$ to $7.23 \mathrm{~g}$ (Table 1). Using a $48 \mathrm{~g} / 100 \mathrm{~mL}$ solution over $10 \mathrm{~g}$ were obtained. A higher efficiency in more concentrated solutions is obtained at the expense of the reaction time needed to reach the maximum product content. At an increase from $23 \mathrm{~g} / 100 \mathrm{~mL}$ to $48 \mathrm{~g} / 100 \mathrm{~mL}$, the time was 2.7 times longer. In solutions containing more water, faster hydrolysis of mannitol derivative was observed, which resulted in a lower final content of the product in the dry mass (Figure 2). As compared to the literature data on the synthesis of galactooligosaccharides the achieved efficiencies are in many cases higher, if applied to dimers synthesis and lower if we consider the total quantity of di- and trimers (the main fractions of galactooligosaccharides). Martínez-Villaluenga et al. [2008] using an enzyme from Kluyveromyces lactis obtained the maximum efficiency of disaccharides at the level of $15.2 \%$ in a $35 \%$ lactose solution $\left(40^{\circ} \mathrm{C}, \mathrm{pH} 7.5,5 \mathrm{~h}\right)$, which reached $30 \%$ together with trisaccharides. Gobinath \& Prapulla [2014] came to a similar fraction profile (13\% of dimers, $17 \%$ of trimers) using $\beta$-galactosidase from Lactobacillus plantarum in a $40 \mathrm{~g} / 100 \mathrm{~mL}$ solution of lactose $\left(\mathrm{pH} 7.0,50^{\circ} \mathrm{C}, 12 \mathrm{~h}\right)$. A similar level of dimer content was observed after using an

TABLE. 1. Influence of lactose and mannitol solution concentration $(1: 1 \mathrm{ratio}, \mathrm{w} / \mathrm{w})$ on the reaction time and quantity of gal-mannitol obtained from $100 \mathrm{~mL}$ of mixture as a result of transgalactosylation using $\beta$-galactosidase from Kluyveromyces lactis. Reaction conditions: $37^{\circ} \mathrm{C}$, pH 6.5, enzyme dose: 11,400 LAU/100 g of lactose.

\begin{tabular}{lc|c}
\hline $\begin{array}{l}\text { Concentration } \\
\text { of lactose and mannitol } \\
\begin{array}{l}\text { solution }(1: 1 \mathrm{w} / \mathrm{w}) \\
(\%(\mathrm{w} / \mathrm{v}))\end{array}\end{array}$ & $\begin{array}{c}\text { Maximum quantity } \\
\text { of gal-mannitol } \\
(\mathrm{g} / 100 \mathrm{~mL} \text { solution })\end{array}$ & $\begin{array}{c}\text { Time to reach } \\
\text { maximum content } \\
\text { of gal-mannitol } \\
(\mathrm{h})\end{array}$ \\
\hline 23 & 4.39 & 1.5 \\
28 & 5.74 & 1.5 \\
33 & 7.23 & 2.5 \\
38 & 8.21 & 3.0 \\
43 & 9.29 & 3.0 \\
48 & 10.2 & 4.0 \\
\hline
\end{tabular}




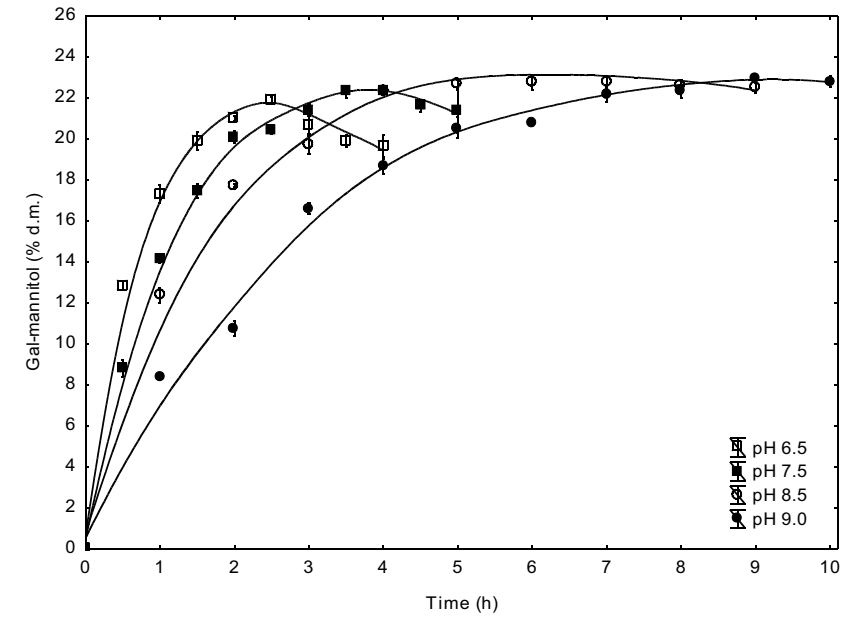

FIGURE 3. Changes in the content of gal-mannitol in the total sugar during synthesis in $33 \mathrm{~g} / 100 \mathrm{~mL}$ solution of lactose and mannitol $(1: 1$ ratio, w/w) depending on the $\mathrm{pH}$ value. Reaction conditions: $37^{\circ} \mathrm{C}, \beta$-galactosidase from Kluyveromyces lactis in the amount of $11400 \mathrm{LAU} / 100 \mathrm{~g}$ of lactose.

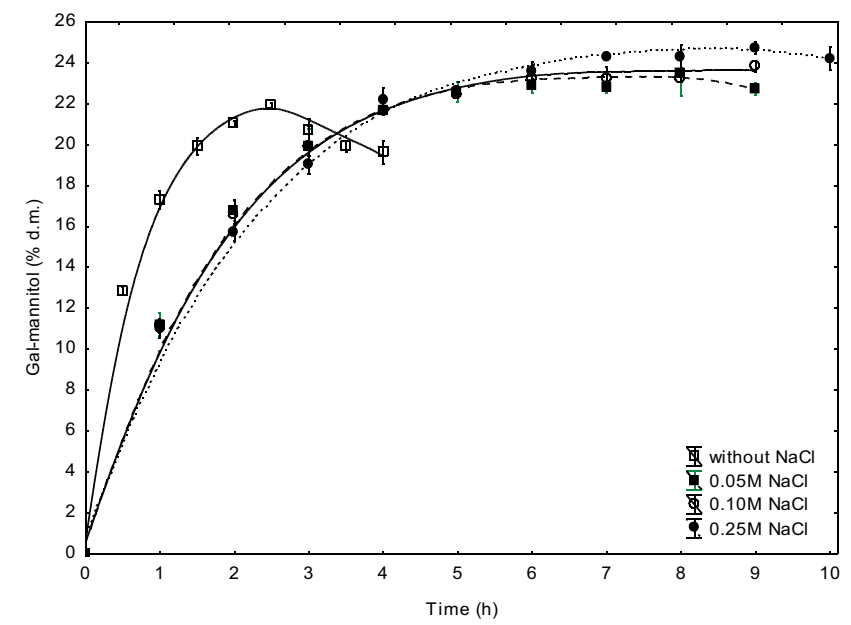

FIGURE 4. Changes in the content of gal-mannitol in the total sugar during synthesis in $33 \mathrm{~g} / 100 \mathrm{~mL}$ solution of lactose and mannitol (1:1 ratio, $\mathrm{w} / \mathrm{w})$ in the presence of $\mathrm{NaCl}$ at a different concentration. Reaction conditions: $37^{\circ} \mathrm{C}, \mathrm{pH} 6.5$, enzyme dose: $11400 \mathrm{LAU} / 100 \mathrm{~g}$ of lactose.

enzyme from Lactobacillus reuteri [Splechtna et al., 2006]. Experiments carried out by Braga et al. [2003] using an enzyme from Kluyveromyces marxianus (35 g lactose $/ 100 \mathrm{~mL}, \mathrm{pH} 7.0$, $40^{\circ} \mathrm{C}$ ) resulted in the total GOS efficiency of $c a .16-21 \%$ (per initial lactose quantity) comparable with gal-mannitol content in the total sugars. Sen et al. [2014] using an immobilised enzyme from Bacillus circulans in $20 \mathrm{~g} / 100 \mathrm{~mL}$ solution of lactose $\left(35^{\circ} \mathrm{C}, \mathrm{pH} 6.5\right.$; in packed bed bioreactor) reached the GOS content of over $8.5 \mathrm{~g} / 100 \mathrm{~mL}$, which indicates more than $42 \%$ content in dry mass. The content of gal-mannitol in the total sugar is in turn higher than in the case of galactosyl derivatives of polyols (sorbitol, xylitol, erythritol) synthesised using an enzyme originating from different microorganisms (14.7-18.8\%) [Klewicki, 2007a]. The mannitol derivative reached a yield of $14.6 \%$ in the experiments performed by $\mathrm{Lu}$ et al. [2010] for $\beta$-galactosidase from Enterobacter cloacae B5 and $o$-nitrophenyl- $\beta$-D-galactopyranoside as a donor.
The $\mathrm{pH}$ value is a parameter which can be significant for the efficiency of transglycosylation products synthesis. An increase in its value is related to conformance changes within the active enzyme centre. They result from the changes in the ionisation condition of acids which occur therein [Zhou \& Chen, 2001]. A greater enzyme capacity for using larger particles than water as an acceptor for galactosyl residues (shift of the reaction balance from hydrolysis towards transglycosylation) can be the effect of conformance changes (also caused by factors other than $\mathrm{pH}$ ). It results in a greater quantity of the synthesised products, e.g. galactooligosaccharides [Giancomini et al., 2002; Bonnin \& Thibault, 1996]. Martinez-Villaluenga et al. [2008] carried out tests using $\beta$-galactosidase from Kluyveromyces lactis in a lactose solution with different $\mathrm{pH}$, reaching an almost $8 \%$ increase in the maximum content of trisaccharides at the $\mathrm{pH}$ increase from 6.5 to 7.5 . In our tests, the quantity of the synthesised gal-mannitol was raised by $\mathrm{ca}$. $5 \%$ by increasing $\mathrm{pH}$ from 6.5 to 9.0 (Figure 3). Gal-sorbitol synthesis conducted in previous tests under similar conditions resulted in an increase about twice as high [Klewicki, 2007b]. A better result can be obtained for mould enzymes from Aspergillus spp. Cardelle-Cobas et al. [2008] obtained an almost three-fold increase in the content of trisaccharides produced by the enzyme from A. aculeatus, increasing the $\mathrm{pH}$ from 4.5 to 6.5 (a significant drop in the produced dimers was observed simultaneously). The reaction was carried out in a $28 \mathrm{~g} / 100 \mathrm{~mL}$ solution of lactose. Previously, delVal \& Otero [2003] achieved an almost 40\% gain in the content of trisaccharides in $30 \mathrm{~g} / 100 \mathrm{~mL}$ solution of lactose using an enzyme from the same source and increasing the $\mathrm{pH}$ from 5.0 to 6.5. Longer time to reach the maximum product concentration is the negative effect of an increase in the $\mathrm{pH}$ value. Gal-mannitol synthesis extended from 2.5 to 9 hours when $\mathrm{pH}$ was raised from 6.5 to 9.0 .

The presence of salt in the reactive mixture was the last tested agent that could increase the quantity of transglycolysation products. It reduces water activity and shifts the enzyme activity from hydrolytic towards synthesis of oligosaccharides [Matsue \& Miyawaki, 2000]. Sodium salt ( $\mathrm{NaCl})$ was used for the tests since sodium ions are mentioned as $\beta$-galactosidase activators [Fischer \& Kleinschmidt, 2015; Zhang et al., 2013]. The use of salt at the concentration of $0.05 \mathrm{~mol} / \mathrm{L}, 0.1 \mathrm{~mol} / \mathrm{L}$ and $0.25 \mathrm{~mol} / \mathrm{L}$ increased the maximum content of gal-mannitol (in the total sugar) by $7.1 \%, 8.7 \%$ and $12.8 \%$ respectively (Figure 4). Furthermore, the presence of salt also causes a favourable effect of impeding the product hydrolysis, which can be easily observed in the case of reactions without salt. The negative effect involves extension of the time necessary to reach the maximum share of mannitol derivative in the total sugar (from $2.5 \mathrm{~h}$ for the option without $\mathrm{NaCl}$ to $7-9 \mathrm{~h}$ for $0.25 \mathrm{~mol} / \mathrm{L} \mathrm{NaCl}$ ). An almost $13 \%$ increase in the content of gal-mannitol is slightly higher than the one obtained for sorbitol derivative (ca. 11\%) [Klewicki, 2007b]. Fortun \& Colas [1991] obtained similar results during synthesis of galactosyl derivative of phenylethanol using an enzyme from Aspergillus oryzae in the presence of $0.5 \mathrm{~mol} / \mathrm{L}$ lithium chloride. Del-Val \& Otero [2003] reported an unfavourable influence of the presence of $\mathrm{NaCl}$ (concentration of up to $15 \mathrm{~g} / 100 \mathrm{~g}$ ) on GOS (trimers) synthesis carried out using $\beta$-galactosidase from Aspergillus aculeatus in PEG 6000 environment. 


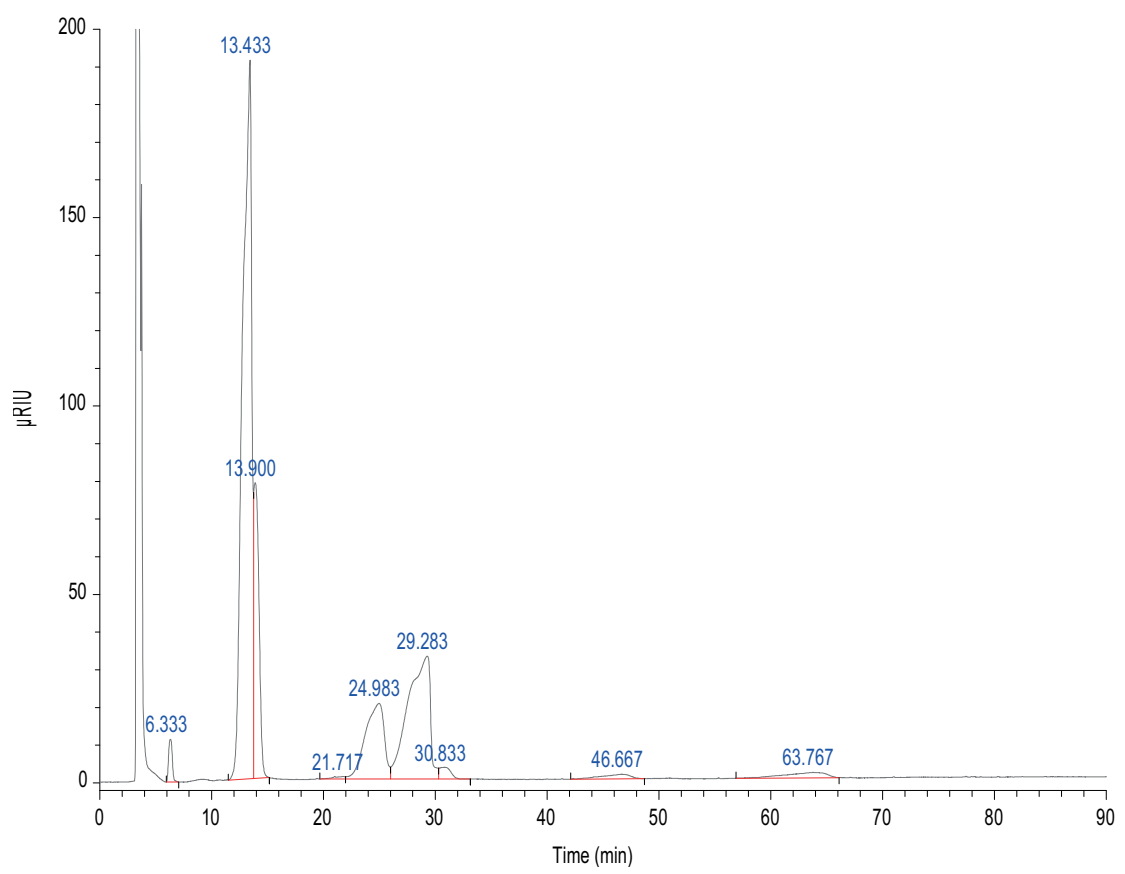

FIGURE 5. HPLC profile of the lactose hydrolysate containing gal-mannitol. Separation conditions: column - Shodex Asahipak $\mathrm{NH}_{2} \mathrm{P}$, mobile phase - acetonitrile: water (80:20 ratio), flow rate $-0.8 \mathrm{~mL} / \mathrm{min}$, detector - RI. Peaks: $6.333 \mathrm{~min}$ - glycerol, $13.433 \mathrm{~min}$ - glucose and galactose, $13.900 \mathrm{~min}$. - mannitol, 21.717 min. - oligosaccharides, 24.983 min. - lactose, 29.283 min. - gal-mannitol, 30.833 min. - oligosaccharides, 46.667 min. - oligosaccharides, 63.767 min. - oligosaccharides.

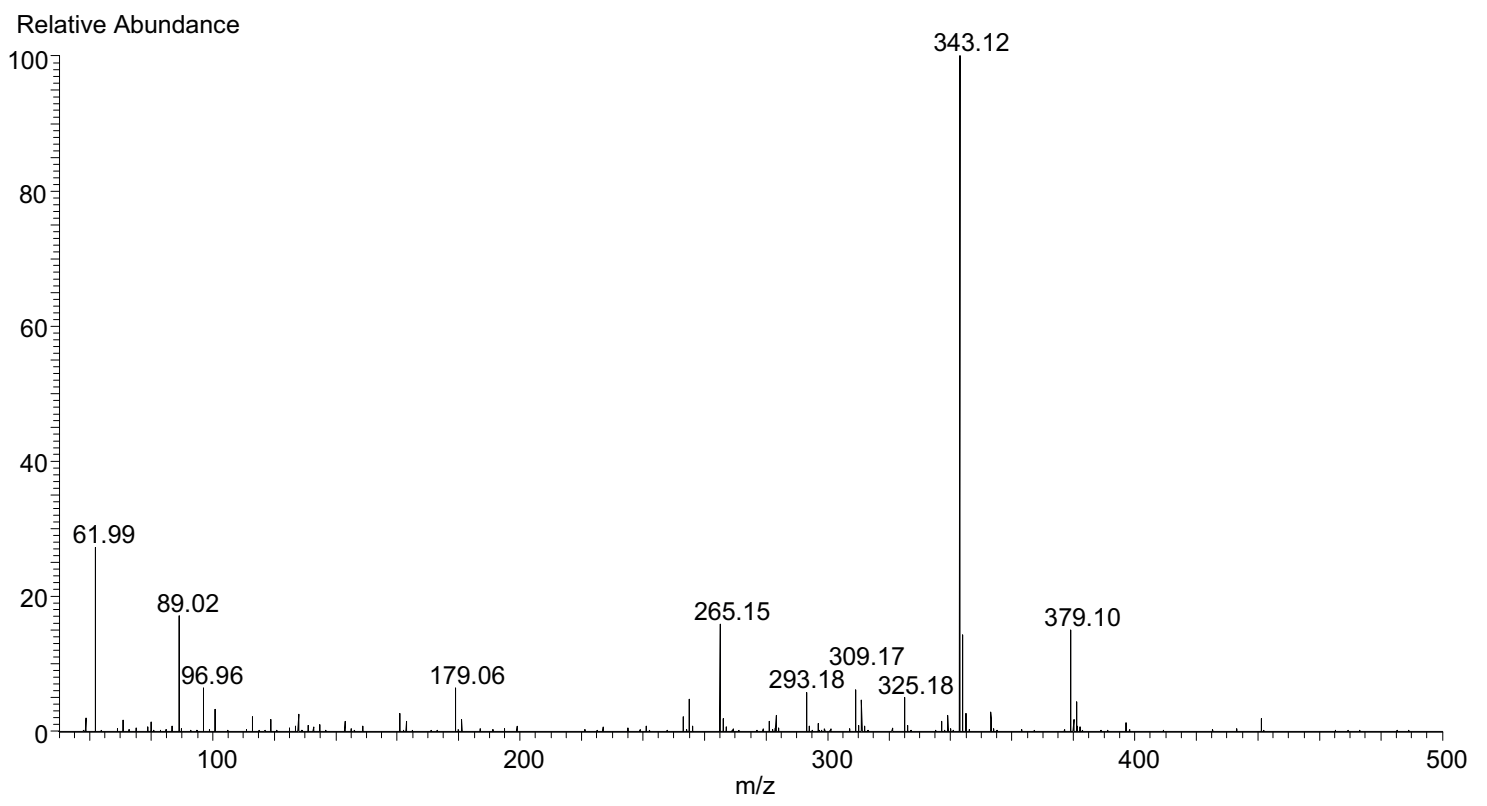

FIGURE 6. MS profile of the gal-mannitol fraction from the HPLC separation (Figure 1, peak - 29.283 min.).

Figure 5 shows a typical HPLC chromatogram. The retention time (RT) of galactosyl-mannitol is $29.283 \mathrm{~min}$. The MS analysis confirmed the legitimacy of assigning the peak to gal-mannitol (molecular mass: 344.3; Figure 6 shows signal $343.12 \mathrm{~m} / \mathrm{z}$ for the negative ion mode). It is known that galactose is mainly attached to the primary hydroxyl of acceptor during transgalactosylation [Shen et al., 2012; Klewicki \& Klewicka, 2004], thus $O$ - $\beta$-D-galactosyl-(1,1)-mannitol was probably the predominant fraction in the product (it needs confirmation). Another oligosaccharides (derived from lac- tose; e.g., RT: $21.717,30.833,46.667)$ were also present however they were not identified.

\section{CONCLUSIONS}

An increase in the enzyme dose over 11,400 LAU/100 g of lactose, by reducing the reaction time contributes to a simultaneous drop in the maximum content of gal-mannitol, which amounts to $21.9 \%$ of total sugar in a $33 \mathrm{~g} / 100 \mathrm{~mL}$ solution, at $37^{\circ} \mathrm{C}$ and $\mathrm{pH} 6.5$. 
The use of solutions at a concentration over $33 \mathrm{~g} / 100 \mathrm{~mL}$ ensures over $21 \%$ gal-mannitol content in the total sugars. The quantity of product obtained individually from $100 \mathrm{~mL}$ of the solution increases from $4.4 \mathrm{~g}$ to over $10 \mathrm{~g}$ at an increase in the concentration of the reactive mixture from $23 \mathrm{~g} / 100 \mathrm{~mL}$ to $48 \mathrm{~g} / 100 \mathrm{~mL}$. A higher efficiency is achieved at the expense of the reaction time by reaching the maximum product content; the time is then 2.7 times longer. Faster hydrolysis of mannitol derivative is observed for solutions with a higher content of water, resulting in a lower final product content in the dry mass.

The $\mathrm{pH}$ increase from 6.5 to 9.0 causes an increase (by $5 \%$ ) in the content of gal-mannitol in the total saccharides to a smaller extent than it is observed for galactooligosaccharides or derivatives of other polyols.

The use of salt concentration ranging from $0.05 \mathrm{~mol} / \mathrm{L}$ to $0.25 \mathrm{~mol} / \mathrm{L}$ contributes to an increase in the maximum content of gal-mannitol within the $7.1-12.8 \%$ range.

\section{RESEARCH FUNDING}

The work was financed from statutory funds of the Institute of Food Technology and Analysis, Faculty of Biotechnology and Food Sciences, Lodz University of Technology.

\section{CONFLICT OF INTEREST}

None declared.

\section{REFERENCES}

1. Bonnin E., Thibault J.-F., Galactooligosaccharide production by transfer reaction of an exogalactanase. Enzyme Microb. Technol., 1996, 19, 99-106.

2. Braga A.R.C., Manera A.P., da Costa Ores J., Sala L., Maugeri F., Kalil S.J., Kinetics and thermal properties of crude and purified $\beta$-galactosidase with potential for the production of galactooligosaccharides. Food Technol. Biotechnol., 2003, 51(1), 45-52.

3. Cardelle-Cobas A., Martínez-Villaluenga C., Sanz M.L., Montilla A., Gas chromatographic-mass spectrometric analysis of galactosyl derivatives obtained by the action of two different $\beta$-galactosidases. Food Chem., 2009, 114, 1099-1105.

4. Cardelle-Cobas A., Villamiel M., Olano A., Corzo N., Study of galacto-oligosaccharide formation from lactose using Pectinex Ultra SP-L. J. Sci. Food Agr., 2008, 88, 954-961.

5. Del-Val M.I., Hill Jr. C.G., Jiménez-Barbero J., Otero C., Selective enzymatic synthesis of 6'-galactosyl lactose by Pectinex Ultra SP in water. Biotechnol. Lett., 2001, 23, 1921-1924.

6. Del-Val M.I., Otero C., Biphasic aqueous media containing polyethylene glycol for the enzymatic synthesis of oligosaccharides from lactose. Enzyme Microb. Technol., 2003, 33, 118-126.

7. Fischer C., Kleinschmidt T., Synthesis of galactooligosaccharides using sweet and acid whey as a substrate. Int. Dairy J., 2015, 48, 15-22.

8. Fortun Y., Colas B., Lithium chloride effect on phenylethyl- $\beta$ $\mathrm{D}$-galactoside synthesis by Aspergillus oryzae $\beta$-D-galactosidase in the presence of high lactose concentration. Biotechnol. Lett., 1991, 13, 863-866.
9. Giancomini C., Irazoqui G., Gonzalez P., Batista-Viera F., Brena B.M., Enzymatic synthesis of galactosyl-xylose by Aspergillus oryzae $\beta$-galactosidase. J. Mol. Catal. B-Enzym., 2002, 19-20, $159-165$.

10. Gobinath D., Prapulla S.G., Permeabilized probiotic Lactobacillus plantarum as a source of $\beta$-galactosidase for the synthesis of prebiotic galactooligosaccharides. Biotechnol. Lett., 2014, 36, 153-157.

11. Guerrero C., Vera C., Conejeros R., Illanes A., Transgalactosylation and hydrolytic activities of commercial preparations of $\beta$-galactosidase for the synthesis of prebiotic carbohydrates. Enzyme Microb. Technol., 2015, 70, 9-17.

12. Hansson T., Andersson M., Wehtje E., Adlercreutz P., Influence of water activity on the competition between $\beta$-glycosidasecatalysed transglycosylation and hydrolysis in aqueous hexanol. Enzyme Microb. Technol., 2001, 29, 527-534.

13. Irazoqui G., Giacomini C., Batista-Viera F., Brena B.M., Cardelle-Cobas A., Corzo N., Jimeno M.L., Characterization of galactosyl derivatives obtained by transgalactosylation of lactose and different polyols using immobilized $\beta$-galactosidase from Aspergillus oryzae. J. Agric. Food. Chem., 2009, 57, 11302$-11307$.

14. Iwasaki K., Nakajima M., Nakao S., Galacto-oligosaccharide production from lactose by an enzymic batch reaction using ß-galactosidase. Process Biochem., 1996, 31, 69-76.

15. Juśkiewicz J., Klewicki R., Zduńczyk Z., Consumption of galactosyl derivatives of polyols beneficially affects cecal fermentation and serum parameters in rats. Nutr. Res., 2006, 26, 531-536.

16. Kim T.-K., Park D.-C., Lee Y.-H., Synthesis of glucosyl-sugar alcohols using glycosyltransferases and structural identification of glucosyl-maltitol. J. Microbiol. Biotechnol., 1997, 7, 310-317.

17. Klewicki R., Effect of selected parameters of lactose hydrolysis in the presence of $\beta$-galactosidase from various sources on the synthesis of galactosyl-polyol derivatives. Eng. Life Sci., 2007a, 7, 268-274.

18. Klewicki R., Formation of gal-sorbitol during lactose hydrolysis with $\beta$-galactosidase. Food Chem., 2007b, 100, 1196-1201.

19. Klewicki R., Klewicka E., Antagonistic activity of lactic acid bacteria as probiotics against selected bacteria of the Enterobaceriacae family in the presence of polyols and their galactosyl derivatives. Biotechnol. Lett., 2004, 26, 317-320.

20. Kurakake M., Okumura T., Morimoto, Y., Synthesis of galactosyl glycerol from guar gum by transglycosylation of $\alpha$-galactosidase from Aspergillus sp. MK14. Food Chem., 2015, 172, 150-154.

21. Linden G., Lorient D., New Ingredients in Food Processing. Biochemistry and Agriculture. 1999, Woodhead Publishing, Cambridge, England, pp. 226-231.

22. Lu L., Xu X., Gu G., Jin L., Xiao M., Wang F., Synthesis of novel galactose containing chemicals by $\beta$-galactosidase from Enterobacter cloacae B5. Bioresour. Technol., 2010, 101, 6868-6872.

23. Lu L.-1., Xiao M., Li Z., Li Y., Wang F., A novel transglycosylating $\beta$-galactosidase from Enterobacter cloacae B5. Process Biochem., 2009, 44, 232-236.

24. Manera A.P., Zabot, G.L., Oliveira J.V., de Oliveira D., Mazutti M.A., Kalil S.J., Treichel H., Maugeri F., Enzymatic synthesis of galactooligosaccharides using pressurised fluids as reaction medium. Food Chem., 2012, 133, 1408-1413.

25. Martínez-Villaluenga C., Cardelle-Cobas A., Corzo N., Olano A., Villamiel M., Optimization of conditions for galactooligosac- 
charide synthesis during lactose hydrolysis by $\beta$-galactosidase from Kluyveromyces lactis (Lactozym 3000 L HP G). Food Chem., 2008, 107, 258-264.

26. Matsue S., Miyawaki O., Influence of water activity and aqueous solvent ordering on enzyme kinetics of alcohol dehydrogenase, lysozyme, and $\beta$-galactosidase. Enzyme Microb. Technol., 2000, 26, 342-347.

27. Nakano H., Kiso T., Okamoto K., Tomita T., Abdul Manan M., Kitahata S., Synthesis of glycosyl glycerol by cyclodextrin glucanotransferases. J. Biosci. Bioeng., 2003, 95, 583-588.

28. Rodriguez-Colinas B., Fernandez-Arrojo L., Ballesteros A.O., Plou F.J., Galactooligosaccharides formation during enzymatic hydrolysis of lactose: Towards a prebiotic-enriched milk. Food Chem., 2014, 145, 388-394.

29. Saarela M., Hallamaa K., Mattila-Sandholm T., Mättö J., The effect of lactose derivatives lactulose, lactitol and lactobionic acid on the functional and technological properties of potentially probiotic Lactobacillus strains. Int. Dairy J., 2003, 13, 291-302.

30. Saha B.C., Racine F.M., Biotechnological production of mannitol and its applications. Appl. Microbiol. Biotechnol., 2011, 89, 879-891.

31. Seki N., Saito H., Lactose as a source for lactulose and other functional lactose derivatives. Int. Dairy J., 2012, 22, 110-115.

32. Sen P., Nath A., Bhattacharjee C., Chowdhury R., Bhattacharya P., Process engineering studies of free and micro-encapsulated $\beta$-galactosidase in batch and packed bed bioreactors for production of galactooligosaccharides. Biochem. Eng. J., 2014, 90 , $59-72$.

33. Sharma P., Sharma B.C., Disaccharides in the treatment of hepatic encephalopathy. Metab. Brain Dis., 2013, 28, 313-320.

34. Shen Q., Yang R., Hua X., Ye F., Wang H., Zhao W., Wang K., Enzymatic synthesis and identification of oligosaccharides obtained by transgalactosylation of lactose in the presence of fructose using $\beta$-galactosidase from Kluyveromyces lactis. Food Chem., 2012, 135, 1547-1554.
35. Shin H.-J., Yang J.-W., Galacto-oligosaccharide production by $\beta$-galactosidase in hydrophobic organic media. Biotechnol. Lett., 1994, 16, 1157-1162.

36. Splechtna B., Nguyen T.-H., Steinböck M., Kulbe K.D., Lorenz W., Haltrich D., Production of prebiotic galacto-oligosaccharides from lactose using $\beta$-galactosidases from Lactobacillus reuteri. J. Agric. Food. Chem., 2006, 54, 4999-5006.

37. Stevenson D.E., Stanley R.A., Furneaux R.H., Optimization of alkyl $\beta$-D-galactopyranoside synthesis from lactose using commercially available $\beta$-galactosidases. Biotechnol. Bioeng., 1993, 42, 657-666.

38. Tzortzis G., Goulas A.K., Gibson G.R., Synthesis of prebiotic galactooligosaccharides using whole cells of a novel strain, $B i$ fidobacterium bifidum NCIMB 41171. Appl. Microbiol. Biotechnol., 2005, 68, 412-416.

39. Wei W., Qi D., Zhao H., Lu Z., Lv F., Bie X., Synthesis and characterisation of galactosyl glycerol by $\beta$-galactosidase catalysed reverse hydrolysis of galactose and glycerol. Food Chem., 2013, 141, 3085-3092.

40. Yanahira S., Morita M., Aoe S., Suguri T., Takada Y., Miura S., Nakajima I., Effects of lactitol-oligosaccharides on calcium and magnesium absorption in rats. J. Nutr. Sci. Vitaminol., 1997, 43(1), 123-132.

41. Zhang H., Li W., Rui X., Sun X., Dong M., Lactobacillus plantarum 70810 from Chinese paocai as a potential source of $\beta$-galactosidase for prebiotic galactooligosaccharides synthesis. Eur. Food Res. Technol., 2013, 236, 817-826.

42. Zhou Q.Z.K., Chen X.D., Effects of temperature and $\mathrm{pH}$ on the catalytic activity of the immobilized $\beta$-galactosidase from Kluyveromyces lactis. Biochem. Eng. J., 2001, 9, 33-40.

Submitted: 17 July 2015. Revised: 27 November 2015 and 28 January 2016. Accepted: 1 February 2016. Published on-line: 5 September 2016 . 
